\title{
Modification and Performance Evaluation of Fertilizer Band Placement Drill Machine for Wheat Crop in Rain-Fed Areas
}

\author{
Muhammad Adnan Islam ${ }^{1 *}, \mathrm{Zia}-\mathrm{U1}-\mathrm{Haq}^{2}$, Rana Shahzad Noor ${ }^{2}$, Matiullah Khan ${ }^{4}$, Muhammad Mohsin \\ Ali $^{1}$, Zulfiqar Ali ${ }^{3}$, Asif Ali Mirani ${ }^{3}$, Hafiz Sultan Mahmood ${ }^{1}$, Muzammil Husain ${ }^{1}$ and Badar Munir Khan \\ Niazi ${ }^{1}$
}

${ }^{1}$ Agricultural Engineering Institute, Pakistan Agricultural Research Council (PARC), Islamabad, Pakistan; ${ }^{2}$ Faculty of Agricultural Engineering and Technology, PMAS Arid Agriculture University, Rawalpindi, 4600, Pakistan; ${ }^{3}$ Agricultural Engineering Division, Pakistan Agricultural Research Council, G-5/1, Islamabad, Pakistan; ${ }^{4}$ Land Resource Research Institute, Pakistan Agricultural Research Council (PARC), Islamabad, Pakistan.

\begin{abstract}
In Pakistan, phosphotic fertilizer such as Diammonium phosphate (DAP) conventionally applied to wheat by broadcast method before sowing crop. This is wasteful method of fertilizer application as only $15-20 \%$ of applied phosphate is utilized by the crop. To overcome the problems of phosphorus fixation, fertilizer band placement drill (FBPD) for wheat had been developed and its performance was evaluated at farmer's fields. This drill places DAP fertilizer near the seed that is about $5 \mathrm{~cm}$ away and $5 \mathrm{~cm}$ deeper than the seed due to which phosphorus use efficiency has increased. Experiments conducted at farmer's fields showed excellent results of fertilizer band placement drill even 50\% DAP was saved with $10 \%$ excess wheat yield. In previous study s results of the fertilizer band placement drill were very encouraging as compare to farmer practice (Rabii Drill). Farmers were reluctant to adopt this fertilizer saving drill due to its heavy weight, which make it difficult to operate by commonly available 50-40 hp tractors. Keeping in view all these issues a low-cost version of fertilizer band placement drill was designed and developed with the help of local manufacturer. Over all Weight reduction (from 450 to $390 \mathrm{~kg}$ ) and changing the drive wheel mechanism (from rear to front) for seed metering was incorporated in modified drill so that it can be easily operated by commonly available $50 \mathrm{hp}$ tractor. After modification, fertilizer band placement drill was tested and compared it with zero tillage drill and rabi drill (farmers practice) by sown wheat in five different location of arid zone of Chakwal. Comparative field testing of three drills shows that FBPD gives significantly more yield as compared to zero till drill and Rabi drill. The effect of fertilizer band placement on all above-mentioned parameter was more pronounced over other two drills, when half bag of DAP was applied. The half bag DAP applied with fertilizer band placement drill gave $24.30 \%$ and $21.38 \%$ increased grain yield over zero-drill and farmers practice (Rabi Drill), respectively. Generally, the fertilizer band placement drill superseded both the drills in comparison at all sites.
\end{abstract}

Received | February 27, 2020; Accepted | December 10, 2020; Published | June 12, 2021

*Correspondence | Muhammad Adnan Islam, Agricultural Engineering Institute, Pakistan Agricultural Research Council (PARC), Islamabad, Pakistan; Email: adnanislam632@yahoo.com

Citation | Islam, M.A., Z.U. Haq, R.S. Noor, M. Khan, M.M. Ali, Z. Ali, A.A. Mirani, H.S. Mahmood, M. Hussain and B.M.K. Niazi. 2021. Modification and performance evaluation of fertilizer band placement drill machine for wheat crop in rain-fed areas. Pakistan Journal of Agricultural Research, 34(3): 417-424.

DOI | https://dx.doi.org/10.17582/journal.pjar/2021/34.3.417.424

Keywords | Fertilizer, Band placement drilll, Rabi drill, Zero till drill, Grain yield 
Introduction

$\mathrm{W}$ Theat is a staple food of Pakistan, out of total 21 million hectares cropped area of Pakistan, wheat is sown at about 8.8 million hectares in which about 8.8 million hectares are irrigated and 1.2 million hectares are under rain fed areas with wheat production of about 25 million tons and 1.7 million tons respectively (Agriculture Statistics of Pakistan, 2017-18). Rain-fed areas make a significant contribution to wheat production in Pakistan. Wheat sowing practices in rain-fed areas are mainly done by traditional Rabi-drill or manual broadcasting method. The available Rabi drills in Rain-fed area is incapable to place seed and fertilizer at desired depth. Wheat is the major crop sown in these areas. Mostly mono cropping is practice in this area; however, groundnut and rapeseed are also practiced in some areas depending upon this quantity and time of rainfall during the year. This climate is considered to be sub-humid according to the Köppen-Geiger climate classification. The temperature here averages $22.3{ }^{\circ} \mathrm{C}$. About $519 \mathrm{~mm}$ of precipitation falls annually. The average yield mainly depends upon the onset of rainfall, which might be reason that lesser fertilizer doses are applied to the crops. Generally, crop yields are for below than the average of irrigated lands. Due to aforementioned factors, the farmers are least adaptive for the modern technologies. Under dose fertilizers application is a general practice. The least fertilizer use efficiency is also due to the uncertain rainfall. Mostly, half to one bag DAP per acre (1.25 to 2.5 bags per hectare) is applied to the wheat crop at the time of sowing through Rabi-Drill. The RabiDrill places fertilizer and seed though single hose at same place in soil while band placement drill had separate hoes for seed and fertilizer.

Fertilizer band placement drill was very economical as compere to Rabii drill and broadcast method of fertilizer application. Fertilizer band placement drill placed fertilizer $5 \mathrm{~cm}$ deep and $5 \mathrm{~cm}$ away from the seed which, not only saved about $50 \%$ fertilizer but also gave $9 \%$ more yield than broadcast method. Economic analyses of fertilizer band placement drill revealed that a former could save about Rs. 3250/ha by using this technology (Ahmed et al., 2004).

In rain fed areas of Pakistan fertilizer use efficiency is very low due to improper placement of seed and low moisture content at the time of sowing. Already developed fertilizer band placement drill was tested in arid zone of District Chakwal in (2016-2017) during wheat sowing season. Germination and tillers of the crop was much better and yield of the crop was found significantly higher than farmer's sowing practices (broad cost and Rabii drill). Keeping in view results and issues of already developed a modified low cost version of fertilizer band placement drill was designed, developed and tested at farmer's field. (Ahmed et al., 1994; Khan et al., 1990) worked on development and evaluation of a low cost zero tillage drill for planting wheat after rice harvest. Their efforts remained successful and at present a number of drills are in use in rice-wheat zone of Pakistan. The seedcum fertilizer drills (including the zero-tillage drill) developed in Pakistan puts fertilizer either far away from the seed or in direct contact with the seed which causes poor efficiency of fertilizer and low yield of the crop. Tests conducted in Pakistan and United States of America have shown, that when ammoniated fertilizers (like DAP) are applied at relatively higher rate, seed germination and crop yield are affected and low crop yield recorded where fertilizer was in contact with the seed (Naz et al., 1999). Despite the fact that proper placement of $\mathrm{P}$ fertilizer is known to improve its use efficiency by crops, such information was not available locally for narrow row crops like wheat. (Matar and Brown, 1989; Rashid, 1992). Rashid et al. (2000) studied phosphorus deficiency and its judicious management in rain-fed wheat in Pakistan, their research adequately established the beneficial impact of $\mathrm{P}$ fertilizer banding in wheat, by drilling $5 \mathrm{~cm}$ away, and $5 \mathrm{~cm}$ deeper than the seed row. These experiments were conducted by using a manual single-row seeder. Subsequently, they proposed to develop an appropriate drill to harvest the fertilizer saving benefits of this technology at the field scale by wheat growers. Deep phosphorus application can be a useful tool to enhance crops yield in semi-arid regions. Distanced application of $\mathrm{P}$ fertilizer is a practical through banding and viable means of increasing grain yield and water use efficiency of rain-fed winter wheat in semi-arid regions, by promoting deep root development of drought-tolerant cultivars (Li-yun, 2014). In another study it was concluded that Band placement was more effective and economical than broadcasting (Rehim et al., 2012). The Agricultural Engineering Institute, PARC developed a fertilizer Band Placement Drill (FBPD), which has the capability to place fertilizer 2 inches each beneath and aside the seed. Such 
placement of fertilizer enhances the efficiency of fertilizers, especially $\mathrm{P}$ fertilizers. The machine was well tested for its fertilizers' efficiency in NARC. In this study this seeding drill was modified and redesign for arid zone. After development the technology was disseminated through demonstration plots, brochures, field days and farmers' meeting on wheat crop in rain-fed (sub-humid) areas of Chakwal.

\section{Modification of fertilizer band placement drill}

Farmers of arid zone areas were unwilling to adopt this fertilizer saving drill due to its heavy weight, which make it difficult to operate by commonly available 50$40 \mathrm{hp}$ tractors. The existing fertilizer band placement drill of 22 tines shown in Figures 1 and 2 was heavy in weight about $450 \mathrm{~kg}$ was redesigned, modified and converted into low cost version of fertilizer band placement drill. Some modification were mad in the design of drill such as reduction of size and transferring drive wheel mounted on the rear to the front of the drill. Following Figures 3, 4, 5 and 6 shows the drawing of modified version of the drill with top view, front view, side view and isometric view of the drill. 22 tines were reduced into 18 tines and over all weight would have been reduce up to $390 \mathrm{~kg}$ from 450 $\mathrm{kg}$. Light weight and modified version of fertilizer band placement was developed for Barani areas by reducing weight of already developed machine. The weight of new drill machine was reduced from 450 $\mathrm{kg}$ to $390 \mathrm{~kg}$ by reducing number of furrow openers from 22 to 18 , so that 50 horsepower tractors can easily pull the FBPD.

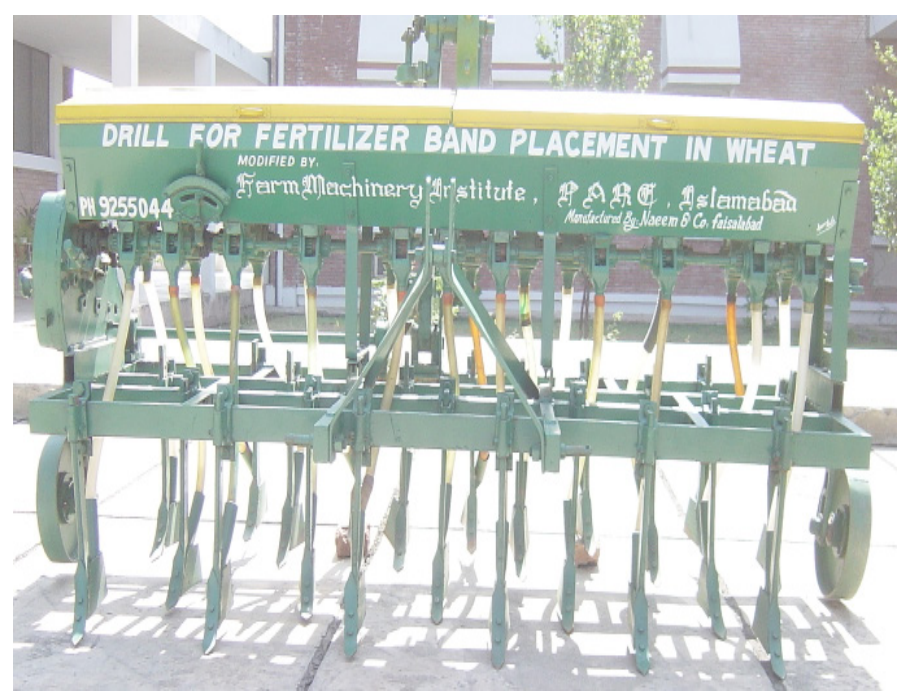

Figure 1: Already developed fertilizer band placement drill.

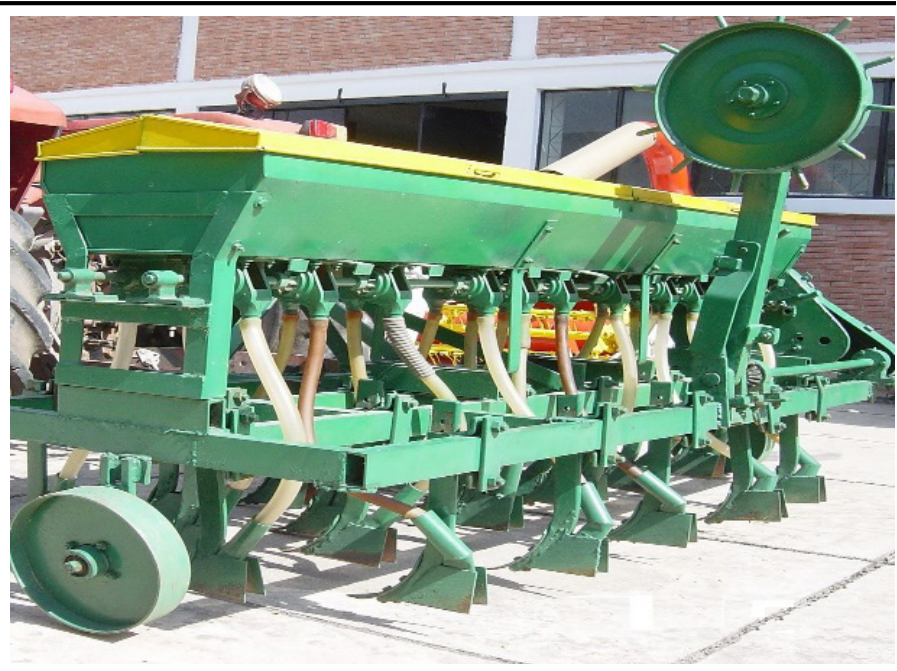

Figure 2: Drive wheel mounted at rear fertilizer band placement drill.

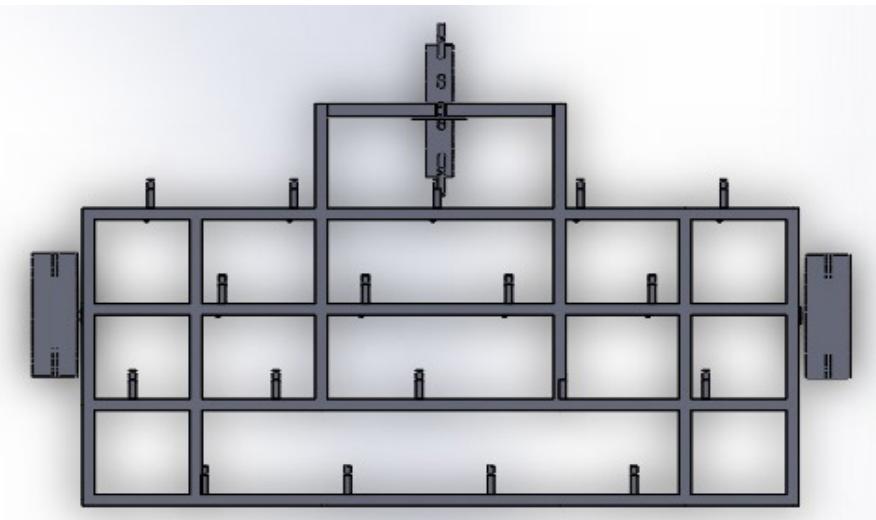

Figure 3: Top view of the drill.

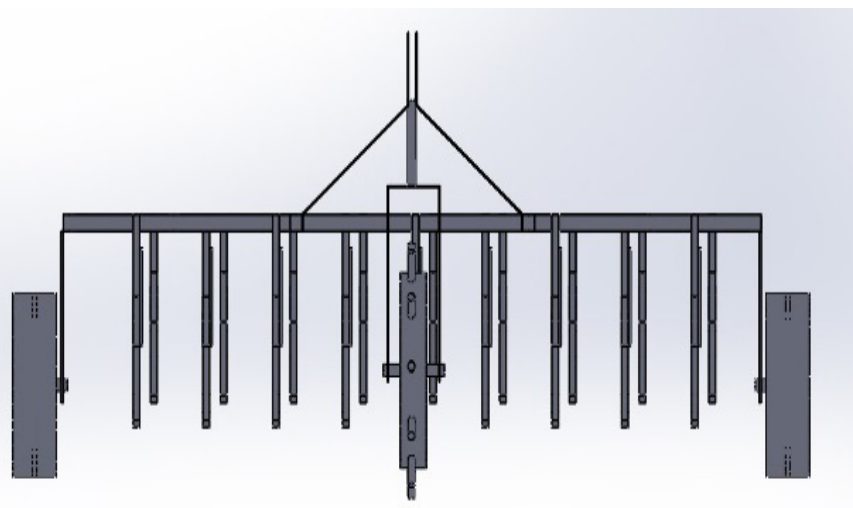

Figure 4: Front view of the drill.

In modified FBPD drive wheel was shifted from rear to front of the drill to keep drill balance and reduce cantilever load on tractor pulling. In Table 1 complete comparison between already existing FBPD and low-cost version (modified version) of the fertilizer band placement drill has been given. As shown in Table 1 overl all width $(1.48 \mathrm{~m})$, length $(1.62 \mathrm{~m})$ and height $(1.2 \mathrm{~m})$ of new modified drill was reduce from width $(2.2 \mathrm{~m})$, length $(2.3 \mathrm{~m})$ and height $(1.15 \mathrm{~m})$ of already exisiting drill. Beside this volume of seed box 
and fertilizer box was also reduced from $0.13 \mathrm{~m}^{3}$ to $0.078 \mathrm{~m}^{3}$. Figures 7 and 8 shows the modified version of fertilizer band placement drill while in figure no 6-drive wheel for seed and fertilizer metering was shifted from rear to front of the drill.

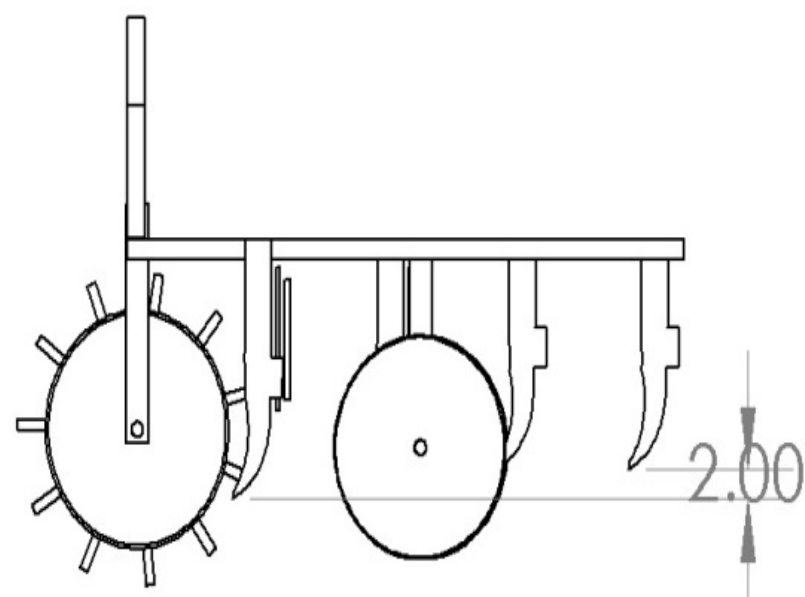

Figure 5: Side view of the drill.

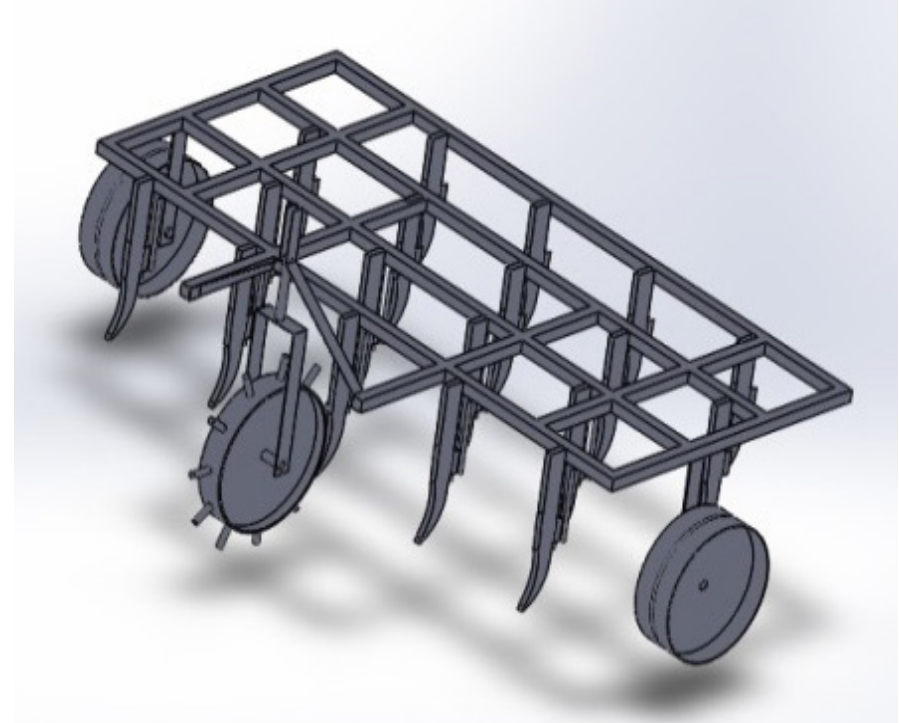

Figure 6: Isometric view of the drill.

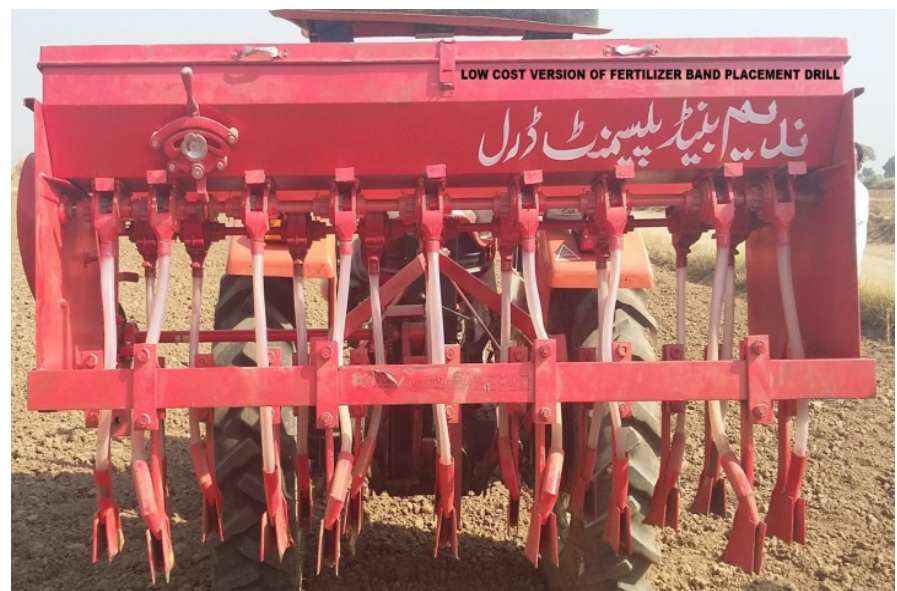

Figure 7: Modified Fertilizer band placement drill.

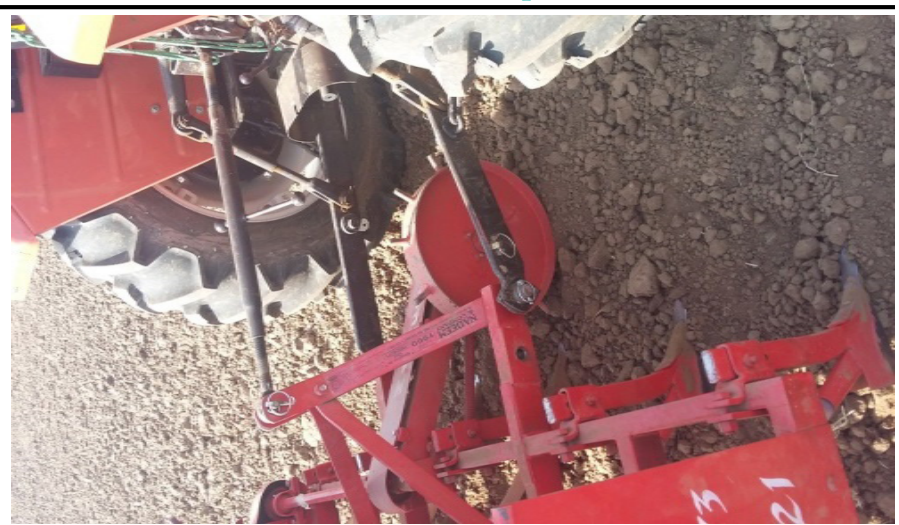

Figure 8: Drive wheel mounted at front.

\section{Field evaluation of drill}

Field selection: Overall, five location were selected for demonstration of the technology in arid zone of district Chakwal in wheat sowing season of 201718 , two each at the village Tharpal, Eastern Chakwal while, three at western side village Bhagwal and Marth. The plot sizes for demonstration varied from 1.5 acres to 2.5 acres.

Seed drill calibration: Before testing each drill was calibrated according to recommended seed and fertilizer application for each treatment.

Soily physical properties: Prior to plantation of the plots, soil samples were randomly collected for physical analyses Such as moisture content, bulk density and penetration resistance of the soil.

Comparative cost analysis: A comparative cost analysis was calculated for three different drills.

Testing and comparative performance evaluation of modified fertilizer band placement drill

Progressive and affective farmers were selected for testing of modified version of fertilizer band placement drill for rain-fed area of district Chakwal. Plantation of wheat demonstration plots was carried out through modified Fertilizer band placement (FBPD) in comparison with zero-drill and the prevailing Rabi-drill (Farmer Practice). Wheat was sown at five different locations in district Chakwal, at every location one acre plot was sown with three different types of drills. In each plot seed bed was prepared with applying two passes of mould-bord (MB) plow and one pass of tine cultivator and single pass of planker would be used to pulverized seed bed for drill sowing. All other soil and crop parameters were considered constant such as moisture content, bulk density, seed rate etc. 
Table 1: Comparison between already existing FBPD and Lost cost version of FBPD.

\begin{tabular}{|c|c|c|c|}
\hline $\begin{array}{l}\text { S. } \\
\text { No }\end{array}$ & Drill description & $\begin{array}{l}\text { Already existing } \\
\text { FBPD }\end{array}$ & $\begin{array}{l}\text { Low cost version } \\
\text { of FBPD }\end{array}$ \\
\hline 1 & Overall weight & $450 \mathrm{~kg}$ & $390 \mathrm{~kg}$ \\
\hline 2 & Overall width & $2.2 \mathrm{~m}$ & $1.48 \mathrm{~m}$ \\
\hline 3 & Overall height & $1.15 \mathrm{~m}$ & $1.2 \mathrm{~m}$ \\
\hline 4 & Overall length & $2.3 \mathrm{~m}$ & $1.62 \mathrm{~m}$ \\
\hline 5 & Volume of seed box & $0.13 \mathrm{~m}^{3}$ & $0.078 \mathrm{~m}^{3}$ \\
\hline 6 & $\begin{array}{l}\text { Volume of fertilizer } \\
\text { box }\end{array}$ & $0.13 \mathrm{~m}^{3}$ & $0.078 \mathrm{~m}^{3}$ \\
\hline 7 & Seed rows & 11 & 9 \\
\hline 8 & Fertilizer rows & 11 & 9 \\
\hline 9 & Drive wheel location & Rear of the drill & Front of the drill \\
\hline 10 & $\begin{array}{l}\text { Effective field ca- } \\
\text { pacity }\end{array}$ & $1.33 \mathrm{acre} /$ hour & 1.17 acre/hour \\
\hline 11 & $\begin{array}{l}\text { Recommended trac- } \\
\text { tor size }\end{array}$ & 50 to $70(\mathrm{hp})$ & 35 to 50 \\
\hline 12 & Manufacturing cost & 95,000 & 80,000 \\
\hline
\end{tabular}

In order to test all these three different machines every plot was divided in to six equal blocks and each block was sown with different seed drill with different fertilizer rate. Following Table 2 is given to explain six different treatments were used to carry out the experiment. In treatment T1 and T2 wheat sowing was don with Rabi drill with $25 \mathrm{~kg}$ and $50 \mathrm{~kg}$ DAP fertilizer. In T3 and T4 wheat was son with FBPD with $25 \mathrm{~kg}$ and $50 \mathrm{~kg}$ DAP fertilizer. Similarly, in T5 and T6 wheat sown was don with Zero Drill with 25 $\mathrm{kg}$ and $50 \mathrm{~kg}$ DAP fertilizer.

Table 2: Treatments description for wheat sowing at one acre area in Chakwal.

$\begin{array}{lll}\text { S. } & \text { Treat- } \\ \text { No } & \text { ment no } & \text { Treatment description } \\ 1 & \text { T1 } & \text { Rabi Drill }+25 \mathrm{~kg} \text { Dap } \\ 2 & \text { T2 } & \text { Rabi Drill }+50 \mathrm{~kg} \text { DAP } \\ 3 & \text { T3 } & \text { Fertilizer Band Placement Drill }+25 \mathrm{~kg} \text { Dap } \\ 4 & \text { T4 } & \text { Fertilizer band placement drill }+50 \mathrm{~kg} \text { DAP } \\ 5 & \text { T5 } & \text { Zero tillage drill +25 kg Dap } \\ 6 & \text { T6 } & \text { Zero tillage Drill }+50 \mathrm{~kg} \text { DAP }\end{array}$

\section{Results and Discussion}

Testing and comparative performance evaluation of fertilizer band placement drill on wheat crop yield as compared to zero till drill and rabbi drill

After development and modification of fertilizer band placement drill, its performance was evaluated and compared by sowing wheat in arid zone of District Chakwal. Wheat was sown with three different types of drills like.

1. Fertilizer band placement drill,

2. Rabi drill

3. Zero tillage drill

Properties of field seed and fertilizer condition is presented in Table 3. Experimental area was rain fed area and soil type was sandy clay loam, while in all fields seedbed were well prepared before sowing Average moisture content of the field was $19 \%$ while average penetration resistance was $1264 \mathrm{kpa}$. Wellknown seed verity Chakwal-50 was used with DAP granular. In two of experimental sites previous crop was groundnut while other three sites were shallow before sowing.

In order to compare their performance one acre of land was divided into six plots. In each plot a different treatment was applied. All six treatments applied for wheat sowing in one acre with three different drills with different fertilizer combinations. Progressive and affective farmers were selected in district Chakwal for plantation of wheat demonstration plots through modified Fertilizer band placement (FBPD) in comparison with zero-drill and the prevailing Rabidrill (Farmer Practice). At all the five demonstration sites wheat was planted on rain-fed soils in District Chakwal area. The data recorded on yield attributes like, biomass yield, Straw yield, number of spike per square meter and number of grains per spike showed similar trend as that of yield (Table 4). The combined mean analyses of all the five sites for grain yield showed that, among the full bag DAP interventions, the highest grain yield of obtained from the intervention where fertilizer was applied through fertilizer band placement drill (FBPD). This intervention of FBPD produced $18.59 \%$ and $11.61 \%$ increased grain yield over Farmer's practice (Rabi drill) and Zero-drill, respectively. The effect of fertilizer band placement on all abovementioned parameter was more pronounced over other two drills, when half bag of DAP was applied. The half bag DAP applied with fertilizer band placement drill gave $24.30 \%$ and $21.38 \%$ increased grain yield over zero-drill and farmers practice (Rabi drill), respectively. Generally, the fertilizer band placement drill superseded both the drills in comparison at all sites, by producing more grain yield, biomass yield, number of spikes per square meter and grain per spike, irrespective of the dose of DAP fertilizer. 
Table 3: Properties of field, seed and fertilizer condition.

$\begin{array}{llllll} & \text { Site-1 } & \text { Site -2 } & \text { Site-3 } & \text { Site-4 } & \text { Site-5 } \\ \text { Location } & \text { Marth (Chakwal) } & \text { Bagwal (Chakwal) } & \text { Bagwal (Chakwal) } & \text { Thrpal (Chakwal) } & \text { Thrpal (Chakwal) } \\ \text { Soil type } & \text { Sandy clay loam } & \text { Sandy clay loam } & \text { Sandy clay loam } & \text { Sandy clay loam } & \text { Sandy clay loam } \\ \text { Tilled / untilled } & \text { Tilled } & \text { Tilled } & \text { Tilled } & \text { Tilled } & \text { Tilled } \\ \text { Irrigated/ Rainfed } & \text { Rainfed } & \text { Rainfed } & \text { Rainfed } & \text { Rainfed } & \text { Rainfed } \\ \text { Moisture content (\%) } & 18 & 19 & 21 & 20 & 22 \\ \text { Penetration resistance (kpa) } & 1300 & 1440 & 1250 & 1280 & 1100 \\ \text { Previous crop } & \text { Ground Nut } & \text { Shallow } & \text { Ground nut } & \text { Shallow } & \text { Shallow } \\ \text { Seed varity } & \text { Chakwal 50 } & \text { Chakwal 50 } & \text { Chakwal 50 } & \text { Chakwal 50 } & \text { Chakwal 50 } \\ \text { Fertilizer type } & \text { DAP granular } & \text { DAP granular } & \text { DAP granular } & \text { DAP granular } & \text { DAP granular }\end{array}$

Table 4: Grain Yield and yield components data of wheat trials planted at various farmers field in Chakwal area (2017-18).

$\begin{array}{llllll}\begin{array}{l}\text { Treat- } \\ \text { ments }\end{array} & \begin{array}{l}\text { Biomass } \\ \left(\mathbf{k g} / \mathbf{h a}^{-1}\right)\end{array} & \begin{array}{l}\text { Straw yield No. } \\ \left(\mathbf{k g} / \mathbf{h a}^{-1}\right)\end{array} & \begin{array}{l}\text { Spo. of } \\ \text { Spikes } \\ \mathbf{m}^{-3}\end{array} & \begin{array}{l}\text { Grain } \\ \text { grains } / \\ \text { spike }\end{array} & \begin{array}{l}\text { Gield } \mathbf{( k g} / \\ \left.\mathbf{h a}^{-1}\right)\end{array} \\ \text { T1 } & 6964 & 4398 & 257 & 38 & 2423 \\ \text { T2 } & 7516 & 4647 & 289 & 39 & 2869 \\ \text { T3 } & 7829 & 4871 & 287 & 40 & 2941 \\ \text { T4 } & 7917 & 4835 & 308 & 43 & 3202 \\ \text { T5 } & 6841 & 4318 & 254 & 36 & 2365 \\ \text { T6 } & 7417 & 4556 & 269 & 38 & 2700\end{array}$

Where; T1: Rabi Drill $25 \mathrm{~kg}$ DAP; T2: Rabi Drill +50kg DAP; T3: FBPD+25 kg DAP; T4: FBPD+50 kg DAP; T5: Zero Drill+25 kg DAP; T6: Zero Drill+50 kg DAP.

In following Figure 9 a combined effect of six different treatments has been shown for wheat crop in rain-fed areas of district Chakwal. As shown in Figure 3 crop parameters such as biomass, straw yield and grain yield were recorded more under treatment T4 (Fertilizer Band Placement Drill+50 kg DAP) as compared to other treatments. Fertilizer Band placement drill gives significantly more yield as well as biomass as compared to other two drills.

Yield comparison of three different drills shown in Table 5 and in Figure 10 shows that mean yield 3202 $\mathrm{kg} / \mathrm{ha}(\mathrm{T} 4=\mathrm{FBPD}+50 \mathrm{~kg}$ DAP) under Fertilizer Band Placement drill (FBPD) was significantly greater than mean yield under Zero till drill 2700 $\mathrm{kg} / \mathrm{ha}$ (T6= Zero Drill+50 kg DAP) and Rabi drill (farmers practice) $2869 \mathrm{~kg} / \mathrm{ha}$ (T2= Rabi Drill $+50 \mathrm{~kg}$ DAP).

\section{Cost analysis}

The comparative operational cost of the drill machines used in this study are given in Table 6 and Figure 11.
The sowing cost with conventional drill (Rs./h 1217), is less than zero drill (Rs. /h 1269), and For fertilizer band placement drill (Rs. /h 1237), sowing cost of conventional drill is low because of low price of drill as compared to other two drills. Figure 11 also depicts the cost of sowing in one hour and sowing cost in one hectare respectively. The operational cost of all three drill did not differ too much but they have significant impact on crop germination and crop yield.

\section{Table 5: Mean grain yield under Fertilizer band placement drill, Rabi drill and zero drill.}

$\begin{array}{lll}\text { S. No } & \text { Drill type } & \text { Mean grain yield (kg/ha) } \\ 1 & \begin{array}{l}\text { Fertilizer band place- } \\ \text { ment drill (FBPD) }\end{array} & 3072 \\ 2 & \text { Rabi Drill } & 2646 \\ 3 & \text { Zero Drill } & 2533\end{array}$

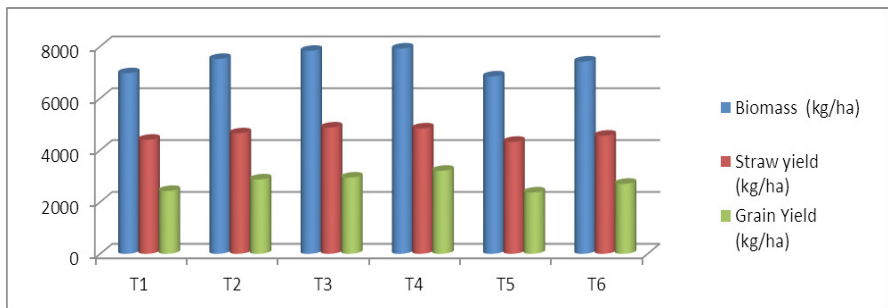

Figure 9: Comparison of three different drills for biomass, straw yield and grain yield.

Where; T1: Rabi Drill+25kg DAP; T2: Rabi Drill+50kg DAP; T3: FBPD+25 kg DAP; T4: FBPD+50 kg DAP; T5: Zero Drill+25 kg DAP; T6: Zero Drill+50 kg DAP.

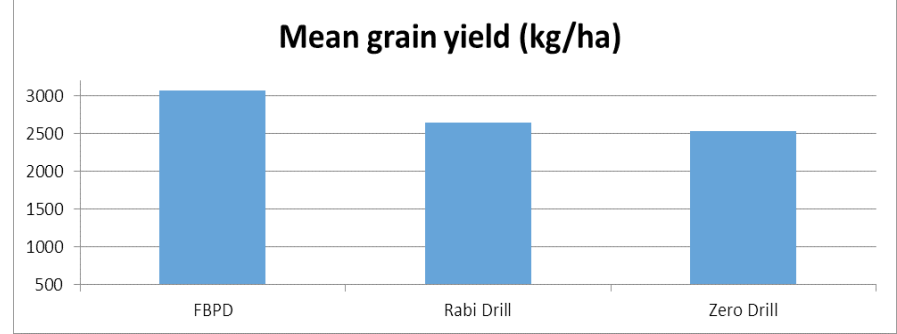

Figure 10: Shows mean grain yield ( $\mathrm{kg} / \mathrm{ha})$ under Fertilizer band placement drill, Rabi drill and zero drill. 
Table 6: Comparison of operational cost of drill for fertilizer band placement, modified FBPD and conventional drill for wheat.

\begin{tabular}{|c|c|c|c|c|}
\hline \multicolumn{5}{|c|}{ Input parameters } \\
\hline & Tractor & $\begin{array}{l}\text { Conven- } \\
\text { tional drill }\end{array}$ & $\begin{array}{l}\text { Zero till- } \\
\text { age drill }\end{array}$ & $\begin{array}{l}\text { Modified } \\
\text { FBPD }\end{array}$ \\
\hline Fixed cost & 850000 & 70000 & 110000 & 85000 \\
\hline Speed $(\mathrm{km} / \mathrm{h})$ & 3 & 3 & 3 & 3 \\
\hline width $(\mathrm{m})$ & & 2.2 & 2.2 & 1.48 \\
\hline Useful life (h) & 10000 & 2000 & 2000 & 2000 \\
\hline Useful life (Year) & 10 & 8 & 8 & 8 \\
\hline $\begin{array}{l}\text { Effective field } \\
\text { capacity }(\mathrm{ha} / \mathrm{h})\end{array}$ & & 0.5384 & 0.5384 & 0.474 \\
\hline $\begin{array}{l}\text { Theoretical field } \\
\text { capacity }\end{array}$ & & 0.66 & 0.66 & 0.444 \\
\hline $\begin{array}{l}\text { Fuel consumption } \\
(\mathrm{L} / \mathrm{h})\end{array}$ & & 7.5 & 7.5 & 7.5 \\
\hline Fuel cost (Rs./L) & & 125 & 125 & 125 \\
\hline $\operatorname{Tax} \%$ & & 2 & 2 & 2 \\
\hline Insurance $\%$ & & 2 & 2 & 2 \\
\hline Housing \% & & 1.5 & 1.5 & 1.5 \\
\hline Labour cost (Rs./h) & & 600 & 600 & 600 \\
\hline Operator cost (Rs.) & & 1800 & 1800 & 1800 \\
\hline Working hours & & 8 & 8 & 8 \\
\hline Salvage value $\%$ & & 10 & 10 & 10 \\
\hline Interest rate $\%$ & & 10 & 10 & 10 \\
\hline \multicolumn{5}{|l|}{ Cost analysis } \\
\hline \multicolumn{5}{|l|}{ Fixed cost } \\
\hline $\begin{array}{l}\text { Depreciation } \\
\text { (Rs./h) }\end{array}$ & 76.5 & 31.5 & 49.5 & 38.25 \\
\hline Interest (Rs./h) & 46.75 & 15.4 & 24.2 & 18.7 \\
\hline $\operatorname{Tax}(\mathrm{Rs} . / \mathrm{h})$ & 17 & 5.6 & 8.8 & 6.8 \\
\hline Insurance (Rs./h) & 17 & 5.6 & 8.8 & 6.8 \\
\hline Housing (Rs./hr) & 12.75 & 4.2 & 6.6 & 5.1 \\
\hline Total fixed cost & 170 & 62.3 & 97.9 & 75.65 \\
\hline \multicolumn{5}{|l|}{ Variable cost } \\
\hline Labour (Rs./h) & & 75 & 75 & 75 \\
\hline Operator (Rs./h) & & 225 & 225 & 225 \\
\hline Fuel cost (Rs./h) & & 504.75 & 504.75 & 504.75 \\
\hline $\begin{array}{l}\text { Lubricant cost } \\
\text { (Rs./h) }\end{array}$ & & 75.7125 & 75.7125 & 75.7125 \\
\hline $\mathrm{R}$ and $\mathrm{M}(\mathrm{Rs} . / \mathrm{h})$ & & 104.5 & 120.5 & 110.5 \\
\hline $\begin{array}{l}\text { Total variable cost } \\
\text { for single field } \\
\text { operation (Rs./h) }\end{array}$ & & 984.96 & 1000.96 & 990.96 \\
\hline $\begin{array}{l}\text { Total FIX cost } \\
\text { (Rs./h) }\end{array}$ & & 223.3 & 268 & 245.65 \\
\hline $\begin{array}{l}\text { Total operational } \\
\text { cost (Rs./h) }\end{array}$ & & 1217 & 1269 & 1237 \\
\hline $\begin{array}{l}\text { Total operational } \\
\text { cost (Rs./ha) }\end{array}$ & & 655 & 683 & 586 \\
\hline
\end{tabular}

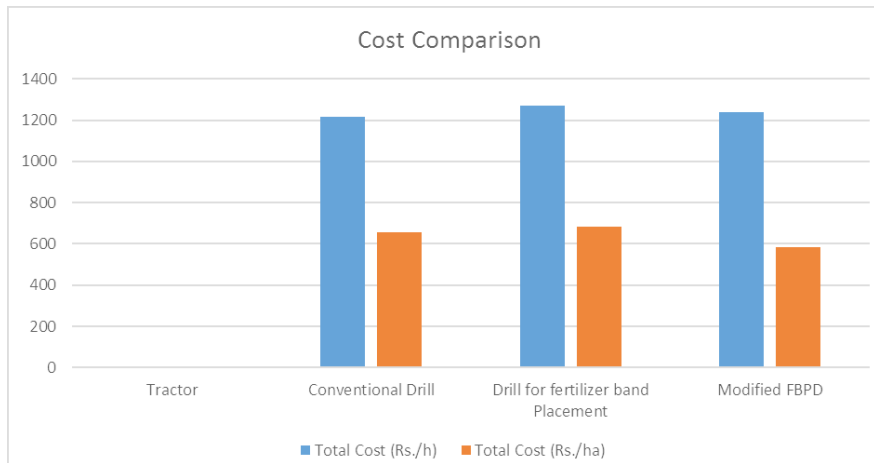

Figure 11: Cost comparison between Conventional drill, Fertilizer band placement drill and modified fertilizer band placement drill $(R s / h)$ and $(R s / h a)$.

\section{Conclusions and Recommendations}

Already existing Fertilizer band placement drill for wheat was modified for rain-fed areas of Pakistan. In modification $60 \mathrm{~kg}$ weight of the modified drill was reduced by reducing overall length, width of drill. Further, wheel drive mechanism was shifted from rear to front of the drill so that 40-50 hp tractor can easily pull the drill machine. Volume of seed box and fertilizer box was also reduced up to $0.052 \mathrm{~m}^{3}$ to carry $100 \mathrm{~kg}$ seed and fertilizer. Furrow openers were also reduced from 22 to 18 so that over all weight of the drill can reduced. The operational cost of all three drill did not differ too much but they have significant impact on crop parameters. Testing and comparative performance evaluation of FBPD with zero till drill and Rabi drill shown that the mean yield $3072 \mathrm{~kg} /$ ha under Fertilizer Band Placement drill (FBPD) was significantly greater than mean yield under Zero till drill $2533 \mathrm{~kg} / \mathrm{ha}$ and Rabi drill (farmers practice) $2646 \mathrm{~kg} / \mathrm{ha}$. Other crop parameters such as biomass, straw yield, no of grains per spike, were more under fertilizer band placement drill as compared to zero till drill at same fertilizer rate and under same field and crop conditions.

\section{Novelty Statement}

This is a very important study in the field of agricultural engineering. By adopting this new modified band placement seed drill technology the sowing cost of farmers could be reduced and also results in increase of wheat yield in rain fed areas. In this study already existing Fertilizer band placement drill for wheat was modified for rain-fed areas of Pakistan.In modification $60 \mathrm{~kg}$ weight of the modified drill was reduced by reducing overall length, width of drill. Further, wheel 
drive mechanism was shifted from rear to front of the drill so that $40-50 \mathrm{hp}$ tractor can easily pull the drill machine. Volume of seed box and fertilizer box was also reduced up to $0.052 \mathrm{~m} 3$ to carry $100 \mathrm{~kg}$ seed and fertilizer. Furrow openers were also reduced from 22 to 18 so that over all weight of the drill can reduced. The operational cost of all three drill did not differ too much but they have significant impact on crop parameters

\section{Author's Contribution}

Muhammad Adnan Islam: Conceived the idea Zia-U1-Haq: Wrote abstract.

Zulfiqar Ali: Wrote methodology.

Asif Ali Mirani: Wrote Conclusion.

Hafiz Sultan Mahmood: Technical input at every step.

Muzammil Husain: Collected data.

Badar Munir Khan Niazi: Data entry.

Muhammad Mohsin Ali: Analyzed the data.

Rana Shahzad Noor: Wrote result and discussion.

Matiullah Khan: Wrote introduction.

\section{Conflict of interest}

The authors have declared no conflict of interest.

\section{References}

Agriculture Statistics of Pakistan, 2017. Ministry of food agriculture and livestock, Govt. of Pakistan, Islamabad.

Ahmad, M., M.A. Zaidi and A.S. Khan. 1994. Development and adaption of No till technology for sowing wheat. Agric. Mech. Asia, Africa, Latin Am., 25(4): 24-28.

Ahmed, M., A. Rashid and A.A. Mirani. 2004. Development and evaluation of fertilizer band placement drill for wheat. J. Eng. Appl. Sci., 123(1).

Khan, A.S., M.A. Tabassum and J. Khan. 1990. Selection of seed-cum-fertilizer drill: Technical Consideration. Agric. Mech. Asia, Africa, Latin Am., 21(1): 35-39.

Li-yun K.A.N.G., Y.U.E. Shan-chao and L.I. Shiqing. 2014. Effects of phosphorus application in different soil layers on root growth, yield, and water-use efficiency of winter wheat grown under semi-arid conditions. J. Integr. Agric. 13(9): 2028-2039. https://doi.org/10.1016/ S2095-3119(14)60751-6

Matar, A.E. and S.C. Brown. 1989. Effect of rate and method of phosphate placement on productivity of durum wheat in Mediterranean environment. Fert. Res., 20: 75-82. https://doi. org/10.1007/BF01055431

Naz, S.Y., K.H. Gill, R. Khalid, S. Ahmad and A. Hussain. 1999. Effect of low rates phosphorus on wheat crop under barani conditions. Pak. J. Soil Sci., 17: 117-119.

Rashid, A., 1992. Phosphorus use efficiency in soils of Pakistan. In: Proc. Symp. on the role of phosphorus in crop production. National Fertilizer Development Centre, Islamabad, pp. 115-129.

Rashid, A., Z.I. Awan, E. Rafique, A. Bhatti and N. Bughio. 2000. Phosphorus deficiency and its judicious management in rain-fed wheat in Pakistan. Final research report of ICARDAIMPHOS funded project. Land Resources Research Institute, NARC, Islamabad.

Rehim, A., M. Farooq, F. Ahmad and M. Hussain. 2012. Band placement of phosphorus improves the phosphorus use efficiency and wheat productivity under different irrigation regimes. Int. J. Agric. Biol., 14: 727-733. 